Review

\title{
Effectiveness of Sling Exercise for Chronic Low Back Pain: A Systematic Review
}

\author{
Jin-Su Lee, PT, PhDc ${ }^{1)}$, Seung-Hoon Yang, PT, PhD'), Yun-Hyung Koog, MD (DKM), PhD ${ }^{3)}$, \\ Hyun-Ju Jun, PT, PhDc ${ }^{1)}$, Se-Hun KIM, PT, PhDc ${ }^{4)}$, KI-Jong KIM, PT, PhDc $\left.{ }^{5}\right)^{*}$ \\ 1) Department of Physical Therapy, Graduate School of Dongshin University, Republic of Korea \\ 2) Department of Physical Therapy, Vision University, Republic of Korea \\ 3) Honam Research Center, Medifarm Hospital, Republic of Korea \\ 4) Department of Physical Therapy, Dongshin University Oriental Hospital, Republic of Korea \\ 5) Department of Physical Therapy, Cheongam College: Deokwol-dong, Sunchon-si, Jeonnam 224-9, \\ Republic of Korea
}

\begin{abstract}
Purpose] This study investigated effects of sling exercise for patients with chronic low back pain. [Methods] We reviewed all relevant papers indexed in PubMed, SCOPUS, and the Cochrane Registered Trials. Eligible trials were randomized controlled trials that compared sling exercise with any type of treatment. We extracted data on muscle thickness, muscle activation, pain, and disability, and assessed the methodological quality of the data. Seven studies met our inclusion criteria. [Results] When sling exercise had an impact on activation of the trunk muscles, increasing the trunk muscle thickness, and the reduction in pain and disability had been assessed shortly after the final exercise session, it was more effective than general exercise at activating trunk muscles, but not more effective at increasing trunk muscle thickness and improving pain and disability than general exercise. [Conclusion] As sling therapy studies are based on a small number of trials, we cannot draw conclusions about the therapeutic effects of sling exercise. When segmental stabilizing exercise and individually designed programs are added to sling exercise, it increases the effectiveness of sling exercise at improving low back pain. This should be the focus of future studies.
\end{abstract}

Key words: Sling exercise, Chronic low back pain, Systematic review

(This article was submitted Jan. 10, 2014, and was accepted Feb. 20, 2014)

\section{INTRODUCTION}

Low back pain is a threat to public health and individuals' economic security ${ }^{1,2)}$. According to comprehensive reviews and epidemiological reports ${ }^{3,4)}$, the prevalence of low back pain ranges from $12 \%$ to $33 \%$, the one-year prevalence ranges from $22 \%$ to $65 \%$, and the lifetime prevalence ranges from $11 \%$ to $84 \%$. Even in African populations where the prevalence of low back pain is believed to be low, it is a burden on society ${ }^{5}$. One study showed that although most patients with acute or persistent low back pain improve markedly within the first six weeks following therapy, pain and disability still remain after one year in some patients ${ }^{6}$.

Trunk muscles contribute to spine stability in healthy individuals with co-activation of trunk flexor and extensor muscles required for the stability of the lumbar spine ${ }^{7)}$. Patients with low back pain have generalized weakness of the trunk muscles ${ }^{8)}$. Some of these muscles are reported to

*Corresponding author. Ki-Jong Kim (E-mail: kjparadise@, hanmail.net)

(C2014 The Society of Physical Therapy Science. Published by IPEC Inc. This is an open-access article distributed under the terms of the Creative Commons Attribution Non-Commercial No Derivatives (by-ncnd) License $<$ http://creativecommons.org/licenses/by-nc-nd/3.0/> . atrophy in adults with lumbar intervertebral disc herniation $^{9,10)}$. There are a number of treatment modalities, such as sling exercise, motor control exercise, ball exercise and general exercise, for activating trunk muscles ${ }^{11,12,24,26)}$. Among these treatments, sling exercise has been widely used in Korea. The sling is a device with a swaying rope that is used to reduce the individual's weight load, similar to performing exercises in water. The unstable nature of sling exercise reduces pain and disability in patients with low back pain ${ }^{13)}$. Sling exercise can improve trunk stability when combined with other types of exercise ${ }^{14)}$. Numerous trials have investigated the effects of sling exercise on low back pain, chronic whiplash-associated disorders, balance, and pelvic girdle pain $\left.{ }^{13}, 15,16\right)$. Nonetheless, no study has reviewed the effectiveness of sling exercise. We therefore investigated whether sling exercise can strengthen trunk muscles and hence reduce pain and disability in patients with low back pain.

\section{SUBJECTS AND METHODS}

We performed a search of PubMed, SCOPUS, and the Cochrane Controlled Trials Register from their inception to December 2012. The search was performed using the search terms [("low back pain" OR "back pain" OR "lumbago" OR "backache") AND "sling"], without language restrictions. 
The types of study were randomized controlled trials. Participants had chronic low back pain with a duration of $>12$ weeks. The types of interventions considered were trials testing sling exercise as a sole therapy or as an adjunct. The types of controls included were any form of treatment including no treatment. The primary outcome measure was muscle attributes measured by ultrasonography (e.g., muscle thickness), electromyography or Tergumed (e.g., maximum voluntary isometric contraction). The secondary outcomes were pain and disability.

We independently extracted data on patient and treatment characteristics. If multiple studies described a single trial, they were considered as one trial. While extracting the data, we encountered a problem. For the muscle strength, most of the eligible trials reported data on the right side of the trunk, but several trials reported data for both sides. To maintain internal consistency, we extracted the data for the the right side. All disagreements were resolved by open discussion.

We independently assessed the methodological quality of the trials using the Physiotherapy Evidence-Based Database (PEDro) scale ${ }^{17}$. One point was awarded whenever a study met one of the following criteria: (1) randomization was performed, (2) allocation was concealed, (3) the group baseline was similar, (4) the patient was blinded, (5) the therapist was blinded, (6) the assessor was blinded, (7) the dropout rate was under $15 \%,(8)$ an intention-to-treat analysis was performed, (9) two groups were compared by statistical analysis; and (10) point measures and variability were reported. When all the items were satisfied, 10 points were awarded. Trials with a PEDro score of greater than 5 are considered to be of moderate-to-high quality ${ }^{18)}$.

\section{RESULTS}

A total of 61 studies were identified: 21 from PubMed, 33 from SCOPUS, six from Cochrane Registered Trials, and one from another source (Fig. 1). Of these, seven trials ${ }^{19-25)}$ were finally included in our analysis. Data from one additional trial, a duplication of the trial by Unsgaard-Tøndel et al., were also included ${ }^{26}$.

Table 1 presents the characteristics of the seven studies were selected for review by this study. Three studies ${ }^{21-23)}$ scored $<6$ on the PEDro scale and the remaining trials scored $\geq 6$. All the studies except one ${ }^{22)}$ involved small numbers of subjects ( $<50$ patients in each group). In total, 209 patients took part in sling exercise, and 274 patients took part in the control program. When one study ${ }^{20)}$, in which the average age of the patients was 70.4 years was excluded, the median age of the patients was 37.8 years (range: 20.3-43.2). The median proportion of female patients was $44.4 \%$ (range: $41.4-69.7$ ) in all trials but one ${ }^{20)}$, which included $90.9 \%$. Regarding the type of control administered, five studies ${ }^{19-22,25)}$ used general exercises, one ${ }^{19)}$ employed a motor control exercise, one ${ }^{23)}$ used manipulation, one ${ }^{24)}$ used a normal bridging exercise, and one ${ }^{24)}$ used a ballbridging exercise.

Muscle thickness ratios assessed by ultrasonography were reported by two studies (Table 2). The study by Vas-

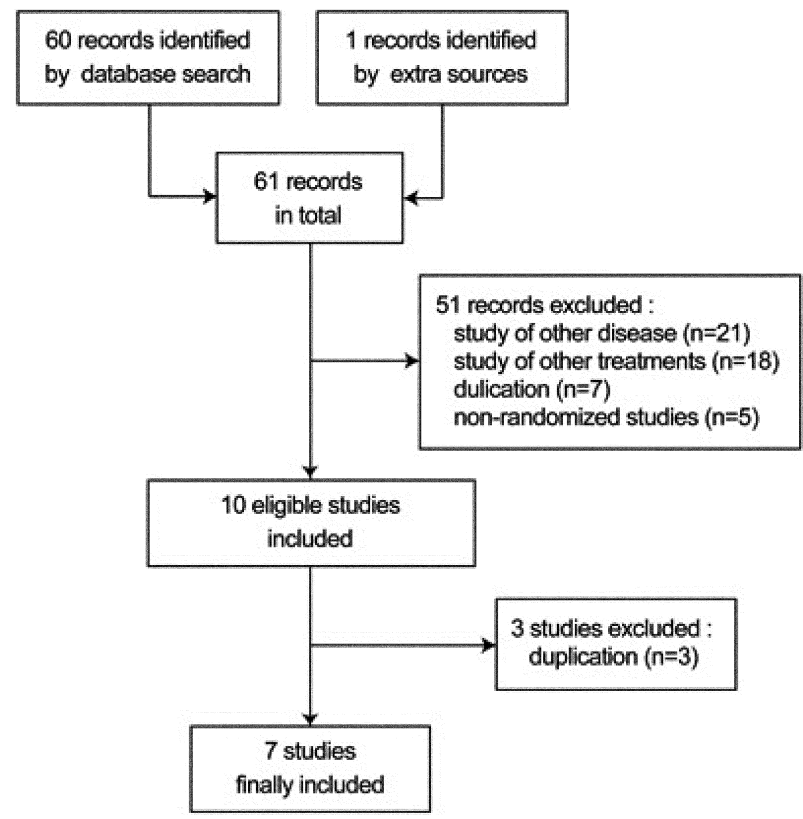

Fig. 1. Flow chart of the study selection procedure.

seljen and Fladmark ${ }^{26}$ ) found that, when the sling exercise was compared with general exercise, it was not more effective at increasing the thickness ratio of the transverse abdominis and obliquus internus. When compared with motor control exercise, the sling exercise was not more effective for the same outcome measures. The study by Saliba et al. ${ }^{25)}$ showed that, when the sling exercise was compared with general exercise, it was not more effective at improving the thickness ratios of the transverse abdominis in a normal stance, a single leg stance, and an unstable surface stance. However, in the hip abduction stance, it had a significant effect on the thickness ratio of the transverse abdominis ( $p$ $<0.05$ ).

Muscle activations evaluated by electromyography or Tergumed were reported by two studies (Table 2). The study by Kang et al. ${ }^{24)}$ found that, when sling exercise was compared with normal bridging or ball-bridging exercises, it was significantly more effective at improving the maximum voluntary isometric contraction of the rectus abdominis, erector spinae, obliquus internus, and multifidus. The study by Yoo and Lee ${ }^{21}$ also showed that compared with general exercises, the sling exercise was significantly more effective at increasing isometric contraction of the erector spine.

Pain outcomes were reported by four studies ${ }^{19-21,23)}$ (Table 3). Three studies compared the sling exercise with general exercise and found that sling exercise did not significantly alleviate low back pain. However, the study by Gao et al. ${ }^{23)}$ showed that sling exercise was more effective than manipulation reducing pain. Only two studies ${ }^{19,20)}$ compared disability outcomes following sling exercise and general exercise (Table 3). They reported that sling exercise did not have any greater effect than general exercise. 
Table 1. Characteristics of studies

\begin{tabular}{|c|c|c|c|c|c|c|}
\hline & \multirow{2}{*}{$\begin{array}{l}\text { Age, } \\
\text { Years } \\
\text { (SD) }\end{array}$} & \multirow[b]{2}{*}{$\begin{array}{l}\text { Female } \\
(\%)\end{array}$} & \multicolumn{2}{|l|}{ PEDro scale } & \multicolumn{2}{|l|}{ Intervention } \\
\hline & & & 10 items* Sum & Experimental group & Control group & $\begin{array}{l}\text { Treatment } \\
\text { duration }\end{array}$ \\
\hline $\begin{array}{l}\text { Yoo, } \\
2012 .{ }^{21)}\end{array}$ & $\begin{array}{l}20.3 \\
(0.6)\end{array}$ & & 10100010115 & $\begin{array}{l}\text { 1. Sling exercise ( } \mathrm{n}=15 \text { ) } \\
\text { (body stretch, standing, pushing the } \\
\text { upper body while seated, } \\
\text { strengthening abdomen while stand- } \\
\text { ing, lying on the front, lying on the } \\
\text { back) }\end{array}$ & $\begin{array}{l}\text { 1. General exercise }(\mathrm{n}=15) \\
\text { (preparatory exercise, belly } \\
\text { blaster, cobra, butterfly, } \\
\text { 3-stage pelvis stability exercise, } \\
\text { hamstring stretch, } \\
\text { folding knees to the chest, } \\
\text { twisting the spine while lying } \\
\text { down, abdominal breathing, cross } \\
\text { extension, cobra) } \\
\text { final abdominal breathing }\end{array}$ & $\begin{array}{l}3 \text { days a week } \\
\text { for } 4 \text { weeks }\end{array}$ \\
\hline $\begin{array}{l}\text { Schröder, } \\
2012 .^{20)}\end{array}$ & $\begin{array}{l}70.4 \\
(5.1)\end{array}$ & $\begin{array}{l}40 \\
(90.9)\end{array}$ & 11100010116 & $\begin{array}{l}\text { 1. Sling exercise }(\mathrm{n}=25) \\
\text { Phase 1:step aerobics, } \\
\text { Phase 2: functional strength exer- } \\
\text { cises focusing on correct posture, } \\
\text { Phase 3: functional strength exer- } \\
\text { cises for global surface muscles of } \\
\text { the torso and dynamic sling, } \\
\text { Phase 4: segmental stabilization, } \\
\text { both static and dynamic (sling), } \\
\text { Phase 5: stretching and relaxation }\end{array}$ & $\begin{array}{l}\text { 1. General exercise }(\mathrm{n}=25) \\
\text { (Phase 1: general keep-fit exer- } \\
\text { cises, } \\
\text { Phase 2: functional strength exer- } \\
\text { cises focusing on correct posture, } \\
\text { Phase 3: functional strength exer- } \\
\text { cises for global surface muscles of } \\
\text { the torso, } \\
\text { Phase 4: segmental stabilization, } \\
\text { both static and dynamic(exercise/ } \\
\text { medical ball), } \\
\text { Phase 5: stretching and relaxation) }\end{array}$ & $\begin{array}{l}2 \text { days a week } \\
\text { for } 12 \text { weeks }\end{array}$ \\
\hline $\begin{array}{l}\text { Ljung- } \\
\text { gren, } \\
1997 .{ }^{22)}\end{array}$ & $\begin{array}{l}39.6 \\
(10.0)\end{array}$ & $\begin{array}{l}56 \\
(44.4)\end{array}$ & 11100000115 & $\begin{array}{l}\text { 1. Sling exercise ( } \mathrm{n}=62 \text { ) } \\
\text { (lateral mobilization of the lower } \\
\text { back, strengthening exercise for the } \\
\text { lower back, strengthening exercise } \\
\text { for the oblique abdominals and the } \\
\text { lower back, strengthening exercise } \\
\text { for the back muscles between the } \\
\text { shoulder blades, strengthening } \\
\text { exercise for the abdominal muscles } \\
\text { of the chest region, strengthen- } \\
\text { ing exercise for the inner thighs, } \\
\text { strengthening exercise for the } \\
\text { abdominal muscles, } \\
\text { applying traction to the back } \\
\text { strengthening exercise for the chest, } \\
\text { shoulder and abdominal muscles }\end{array}$ & $\begin{array}{l}\text { 1. General exercise ( } \mathrm{n}=62 \text { ) } \\
\text { (lifting the upper body in a hookly- } \\
\text { ing position, } \\
\text { Lifting the uppermost leg in a } \\
\text { sidelying position, } \\
\text { stretching the arm forwards and } \\
\text { the opposite leg backwards while } \\
\text { creeping, } \\
\text { Lifting the upper body in a prone } \\
\text { push up, } \\
\text { lifting the feet off the floor in a } \\
\text { prone position, } \\
\text { standing up with the objects, } \\
\text { trunk rotation, trunk bending) }\end{array}$ & $\begin{array}{l}3 \text { days a week } \\
\text { for } 1 \text { year }\end{array}$ \\
\hline $\begin{array}{l}\text { Gao, } \\
2008 .^{23)}\end{array}$ & $\begin{array}{l}36.0 \\
(4.1)\end{array}$ & $\begin{array}{l}12 \\
(41.4)\end{array}$ & 10101111004 & 1. Sling exercise $(n=15)$ & 1. Manipulation $(n=14)$ & $\begin{array}{l}5 \text { days a week } \\
\text { for } 8 \text { weeks }\end{array}$ \\
\hline $\begin{array}{l}\text { Kang, } \\
2012 . .^{24)}\end{array}$ & $\begin{array}{l}43.2 \\
(7.5)\end{array}$ & $\begin{array}{l}13 \\
(43.3)\end{array}$ & 11100011117 & $\begin{array}{l}\text { 1. Sling exercise }(n=30) \\
\text { (sling bridging exercise) }\end{array}$ & $\begin{array}{l}\text { 1. General exercise }(\mathrm{n}=30) \\
\text { (normal bridging exercise) } \\
\text { 2. Ball exercise }(\mathrm{n}=30) \\
\text { (ball bridging exercise) }\end{array}$ & 1 day \\
\hline $\begin{array}{l}\text { Un- } \\
\text { sgaard- } \\
\text { Tøndel, } \\
2010 .{ }^{19)}\end{array}$ & $\begin{array}{l}40.1 \\
(10.7)\end{array}$ & $\begin{array}{l}76 \\
(69.7)\end{array}$ & 11100110117 & $\begin{array}{l}\text { 1. Sling exercise }(\mathrm{n}=36) \\
\text { (back exercise in sling) }\end{array}$ & $\begin{array}{l}\text { 1. Motor control exercise }(\mathrm{n}=36) \\
\text { (abdominal drawing-in maneuver) } \\
\text { 2. General exercise }(\mathrm{n}=37) \\
\text { (general trunk strengthening and } \\
\text { stretching exercises) }\end{array}$ & $\begin{array}{l}1 \text { day a week } \\
\text { for } 8 \text { weeks }\end{array}$ \\
\hline $\begin{array}{l}\text { Saliba, } \\
2010 . .^{25)}\end{array}$ & $\begin{array}{l}23.1 \\
(6.0)\end{array}$ & $\begin{array}{l}33 \\
(64.7)\end{array}$ & 11100110117 & $\begin{array}{l}\text { 1. Sling exercise }(\mathrm{n}=26) \\
\text { (sling bridging exercise) }\end{array}$ & $\begin{array}{l}\text { 1. General exercise }(\mathrm{n}=25) \\
\text { (general bridging exercise) }\end{array}$ & 1 day \\
\hline
\end{tabular}

*Ten items of PEDro scale: (1) randomization was performed; (2) allocation was concealed; (3) group baseline was similar; (4) patient was blinded; (5) therapist was blinded; (6) assessor was blinded; (7) dropout rate was under 15\%; (8) intention-to-treat analysis was performed; (9) two groups were compared by statistical analysis; and (10) point measures and variability were reported. 
1304 J. Phys. Ther. Sci. Vol. 26, No. 8, 2014

Table 2. Effects of sling exercise on primary outcome

\begin{tabular}{|c|c|c|c|c|c|c|c|}
\hline & \multirow{2}{*}{$\begin{array}{l}\text { Measure- } \\
\text { ment time }\end{array}$} & \multirow{2}{*}{$\begin{array}{l}\text { Control } \\
\text { group }\end{array}$} & \multicolumn{5}{|l|}{ Muscle type } \\
\hline & & & Transverse abdominis & $\begin{array}{c}\text { Rectus } \\
\text { abdominis }\end{array}$ & Erector spinae & $\begin{array}{l}\text { Obliquus } \\
\text { internus }\end{array}$ & Multifidus \\
\hline \multicolumn{8}{|c|}{ Muscle thickness ratio* } \\
\hline \multirow[t]{2}{*}{$\begin{array}{l}\text { Vasseljen, } \\
2010 . .^{26)}\end{array}$} & 2 months & $\begin{array}{l}\text { 1. General } \\
\text { exercise }\end{array}$ & $\mathrm{p}>0.05$ & NA & NA & $\mathrm{p}>0.05$ & NA \\
\hline & & $\begin{array}{l}\text { 2. Motor } \\
\text { control } \\
\text { exercise }\end{array}$ & $\mathrm{p}>0.05$ & NA & NA & $\mathrm{p}>0.05$ & NA \\
\hline $\begin{array}{l}\text { Saliba, } \\
2010 .{ }^{25)}\end{array}$ & 1 day & $\begin{array}{l}\text { 1. General } \\
\text { exercise }\end{array}$ & $\begin{array}{l}\text { Normal stance: } \\
p=0.29 \\
\text { Single leg stance: } \\
p=0.79 \\
\text { Unstable stance: } \\
p=0.41 \\
\text { Hip abduction: } p=0.04\end{array}$ & NA & NA & NA & NA \\
\hline \multicolumn{8}{|c|}{ Muscle activation } \\
\hline \multirow[t]{2}{*}{$\begin{array}{l}\text { Kang, } \\
2012 .{ }^{24)}\end{array}$} & 1 day & $\begin{array}{l}\text { 1. Normal } \\
\text { bridging } \\
\text { exercise }\end{array}$ & & $\begin{array}{l}\text { Maximum vol- } \\
\text { untary isomet- } \\
\text { ric contraction: } \\
\mathrm{p}<0.05\end{array}$ & $\begin{array}{l}\text { Maximum vol- } \\
\text { untary isomet- } \\
\text { ric contraction: } \\
\mathrm{p}<0.05\end{array}$ & $\begin{array}{l}\text { Maximum vol- } \\
\text { untary isomet- } \\
\text { ric contraction: } \\
\mathrm{p}<0.05\end{array}$ & $\begin{array}{l}\text { Maximum vol- } \\
\text { untary isomet- } \\
\text { ric contraction: } \\
\mathrm{p}<0.05\end{array}$ \\
\hline & & $\begin{array}{l}2 . \text { Ball } \\
\text { bridging } \\
\text { exercise }\end{array}$ & & $\begin{array}{l}\text { Maximum vol- } \\
\text { untary isomet- } \\
\text { ric contraction: } \\
\mathrm{p}<0.05\end{array}$ & $\begin{array}{l}\text { Maximum vol- } \\
\text { untary isomet- } \\
\text { ric contraction: } \\
\mathrm{p}<0.05\end{array}$ & $\begin{array}{l}\text { Maximum vol- } \\
\text { untary isomet- } \\
\text { ric contraction: } \\
\mathrm{p}<0.05\end{array}$ & $\begin{array}{l}\text { Maximum vol- } \\
\text { untary isomet- } \\
\text { ric contraction: } \\
\mathrm{p}<0.05\end{array}$ \\
\hline Yoo, 2012. ${ }^{21)}$ & 1 month & $\begin{array}{l}\text { 1. General } \\
\text { exercise }\end{array}$ & & & $\begin{array}{l}\text { Isometric } \\
\text { contraction: } \\
\mathrm{p}<0.05\end{array}$ & & \\
\hline
\end{tabular}

NA, not applicable. * Ratios were calculated by dividing the thickness of the contracted muscle by that of the resting muscle.

\section{DISCUSSION}

This study investigated the effects of sling exercise therapy on the trunk muscle thickness ratio, muscle activation, pain, and disability. When the impact of sling exercise on the thickness of the trunk muscles was examined after the final treatment, it was not more effective than general exercise and motor control exercise at increasing the muscle thickness. However, hip abduction showed greater improvement in sling exercise groups than in control groups. After the intervention sling exercise was more effective than normal bridging exercise, ball-bridging exercise or general exercise at increasing trunk muscle activation. However, it was not more effective than general exercise at reducing pain or disability, although it was more effective than manipulation at reducing pain.

The trunk muscles of patients with low back pain show atrophy ${ }^{27}$. Pain changes the contraction pattern of trunk muscles and inhibits their activation ${ }^{28)}$, eliciting atrophy of the trunk muscles. Also, patients with low back pain exhibit delayed contraction of the trunk deep muscles ${ }^{29)}$. Trunk stability depends on normal recruitment of the deep muscles. Therefore, delayed contraction of these muscles causes instability of the trunk $\mathrm{k}^{30}$. Previous investigations have found that trunk muscle strengthening and normal recruitment of the trunk muscles through neural adaption are effective at reducing pain and disability and improving trunk stability ${ }^{31,32)}$. Therefore, trunk muscle strengthening and neural adaption via sling exercise can be expected to reduce the pain and disability of patients with low back pain.

Regarding muscle thickness, a previous study reported that motor control exercise was more effective than general exercise at increasing the muscle thickness of the transversus abdominis and lumbar multifidus ${ }^{33)}$. Two other studies found that motor control exercise can increase the muscle thicknesses of the transversus abdominis and multifidus more than those of the other trunk muscles ${ }^{29,34)}$. In the studies selected for this review, sling exercise did not improve the muscle thickness of the transverse abdominis. Another study reported that 10 weeks of stabilization training combined with dynamic-static resistance training was more effective than general stabilization exercise or dynamic resistance training at increasing the thickness of the lumbar multifidus ${ }^{35)}$. None of the studies reviewed in the present study presented any rationale for a particular duration of therapy. Changing the muscle thickness needs prolonged treatment over 10 weeks $^{36}$ ). Therefore, the duration of the sling exercise applied in each trial may have been too short to increase the muscle thickness.

Regarding muscle activation, one study reported that bridging exercise on a Swiss ball was more effective at increasing trunk muscle activity than bridging exercise off a 
Table 3. Effects of sling exercise on other outcomes

\begin{tabular}{lllll}
\hline & $\begin{array}{l}\text { Measurement } \\
\text { time point }\end{array}$ & Control group & Pain & Disability \\
\hline $\begin{array}{l}\text { Unsgaard-Tøndel, } \\
\text { 2010. }{ }^{19)}\end{array}$ & 2 months & General exercise & $0-10$ numeric pain scale: $\mathrm{p}>0.05$ & Oswestry disability index: $\mathrm{p}>0.05$ \\
Schröder, 2012. ${ }^{20)}$ & 3 months & General exercise & Pain domain of Qualeffo-41: $\mathrm{p}=0.43$ & Physical domain of Qualeffo-41: $\mathrm{p}=0.94$ \\
Yoo, 2012. ${ }^{21)}$ & 1 month & General exercise & $0-10$ visual analogue scale: $\mathrm{p}>0.05$ & \\
Gao, 2008. ${ }^{23)}$ & 2 months & Manipulation & $0-10$ numeric pain scale: $\mathrm{p}<0.01$ & \\
\hline
\end{tabular}

Swiss ball ${ }^{36)}$. There are some agreements between the results of this previous study and the findings of the present review. The similarities can be explained by the nature of the exercise surface. An unstable surface is more effective at increasing trunk muscle activation ${ }^{37}$ ). Therefore, the unstable characteristics of sling exercise may be more effective than general exercise at activating muscle activity. A long-term intervention does not seem to be needed. Another study reported that muscle activity was changed by neural adaptation through therapy lasting from days to a few weeks ${ }^{38)}$. As noted above, despite the short-term nature of the intervention, sling exercise is more effective than general exercise at activating muscle activity.

Regarding pain and disability, a previous systematic review proposed strategies consisting of individually designed programs to improve pain and disability for nonspecific chronic low back pain ${ }^{39)}$. Rackwitz et al. stated that segmental stabilizing exercises are more effective than treatment by a general practitioner for reducing the pain and disability of patients with low back pain ${ }^{40)}$. In the present review, the sling exercises in the trials were not more effective than general exercise at reducing pain and disability. This discrepancy between the previous systematic review and our review can be explained by the nature of the programs. First, the treatment methods in the trials included in this review did not include segmental stabilizing exercises. Therefore, the sling exercise conducted in the studies reviewed may have been of insufficient intensity to reduce pain and disability. Second, sling exercise did not consist of individually designed programs.

Although this is the first review of the impact of sling exercise on low back pain, several considerations should be taken into account. In three $(42.9 \%)$ of the seven studies examined, there was no mention of receipt of approval from an ethical review board ${ }^{21,23,24)}$. Two studies did not state whether informed consent was obtained from the patients $^{21,23)}$. Also, there were a small number of studies that were methodologically sound and had sufficient statistical power. As our review was based on a small number of trials, its conclusion are limited. Few trials have evaluated the effect of sling exercise over the long term. Hence, we cannot offer any broad insight into the therapeutic effect of sling exercise. The addition of segmental stabilizing exercise and individually designed programs to sling exercise programs should increase the effectiveness of sling exercise at reducing low back pain. This should be the focus of future studies.

\section{REFERENCES}

1) Maniadakis N, Gray A: The economic burden of back pain in the UK. Pain, 2000, 84: 95-103. [Medline] [CrossRef]

2) Maetzel A, Li L: The economic burden of low back pain: a review of studies published between 1996 and 2001. Best Pract Res Clin Rheumatol, 2002, 16: 23-30. [Medline] [CrossRef]

3) Hoy D, Bain C, Williams G, et al.: A systematic review of the global prevalence of low back pain. Arthritis Rheum, 2012, 64: 2028-2037. [Medline] [CrossRef]

4) Walker BF: The prevalence of low back pain: a systematic review of the literature from 1966 to 1998. J Spinal Disord, 2000, 13: 205-217. [Medline] [CrossRef]

5) Louw QA, Morris LD, Grimmer-Somers K: The prevalence of low back pain in Africa: a systematic review. BMC Musculoskelet Disord, 2007, 8: 105. [Medline] [CrossRef]

6) da C Menezes Costa L, Maher CG, Hancock MJ, et al.: The prognosis of acute and persistent low-back pain: a meta-analysis. CMAJ, 2012, 184: E613-E624. [Medline] [CrossRef]

7) Cholewicki J, Panjabi MM, Khachatryan A: Stabilizing function of trunk flexor-extensor muscles around a neutral spine posture. Spine, 1997, 22: 2207-2212. [Medline] [CrossRef]

8) Suzuki N, Endo S: A quantitative study of trunk muscle strength and fatigability in the low-back-pain syndrome. Spine, 1983, 8: 69-74. [Medline] [CrossRef]

9) Yoshihara K, Shirai Y, Nakayama Y, et al.: Histochemical changes in the multifidus muscle in patients with lumbar intervertebral disc herniation. Spine, 2001, 26: 622-626. [Medline] [CrossRef]

10) Zhao WP, Kawaguchi Y, Matsui H, et al.: Histochemistry and morphology of the multifidus muscle in lumbar disc herniation: comparative study between diseased and normal sides. Spine, 2000, 25: 2191-2199. [Medline] [CrossRef]

11) O'Sullivan PB: Lumbar segmental 'instability': clinical presentation and specific stabilizing exercise management. Man Ther, 2000, 5: 2-12. [Medline] [CrossRef]

12) Koumantakis GA, Watson PJ, Oldham JA: Trunk muscle stabilization training plus general exercise versus general exercise only: randomized controlled trial of patients with recurrent low back pain. Phys Ther, 2005, 85: 209-225. [Medline]

13) Stray-Pedersen JI, Magnussen R, Kuffel E, et al.: Sling exercise training improves balance, kicking velocity and torso stabilization strength in elite soccer players. Med Sci Sports Exerc, 2006, 38: S243. [CrossRef]

14) Kim SY, Kwon JH: Lumbar stabilization exercises using the sling system. Korean J Orthop Manu Ther, 2001, 7: 23-39.

15) Vikne J, Oedegaard A, Laerum E, et al.: A randomized study of new sling exercise treatment vs traditional physiotherapy for patients with chronic whiplash-associated disorders with unsettled compensation claims. J Rehabil Med, 2007, 39: 252-259. [Medline] [CrossRef]

16) Stuge B, Holm I, Vøllestad N: To treat or not to treat postpartum pelvic girdle pain with stabilizing exercises? Man Ther, 2006, 11: 337-343. [Medline] [CrossRef]

17) PEDro scale: Physiotherapy Evidence Database. http://www.pedro.org.au/ English/\% -20downloads/pedro-scale (Accessed Mar. 2013)

18) Moseley AM, Herbert RD, Sherrington C, et al.: Evidence for physiotherapy practice: a survey of the Physiotherapy Evidence Database (PEDro). Aust J Physiother, 2002, 48: 43-49. [Medline] [CrossRef]

19) Unsgaard-Tøndel M, Fladmark AM, Salvesen $\varnothing$, et al.: Motor control exercises, sling exercises, and general exercises for patients with chronic low back pain: a randomized controlled trial with 1-year follow-up. Phys Ther, 2010, 90: 1426-1440. [Medline] [CrossRef]

20) Schröder G, Knauerhase A, Kundt G, et al.: Effects of physical therapy on 
quality of life in osteoporosis patients - a randomized clinical trial. Health Qual Life Outcomes, 2012, 10: 101. [Medline] [CrossRef]

21) Yoo YD, Lee YS: The effect of core stabilization exercises using a sling on pain and muscle strength of patients with chronic low back pain. J Phys Ther Sci, 2012, 24: 671-674. [CrossRef]

22) Ljunggren $\mathrm{AE}$, Weber $\mathrm{H}, \mathrm{Kogstad} \mathrm{O}$, et al.: Effect of exercise on sick leave due to low back pain. A randomized, comparative, long-term study. Spine, 1997, 22: 1610-1616, discussion 1617. [Medline] [CrossRef]

23) Gao B, Rong $X$, Liang D: The effect of sling exercise therapy on low back pain caused by exercises training. Chin J Rehabil Med, 2008, 23: 10951097.

24) Kang H, Jung J, Yu J: Comparison of trunk muscle activity during bridging exercises using a sling in patients with low back pain. J Sports Sci Med 2012, 11: 510-515. [Medline]

25) Saliba SA, Croy T, Guthrie R, et al.: Differences in transverse abdominis activation with stable and unstable bridging exercises in individuals with low back pain. N Am J Sports Phys Ther, 2010, 5: 63-73. [Medline]

26) Vasseljen O, Fladmark AM: Abdominal muscle contraction thickness and function after specific and general exercises: a randomized controlled tria in chronic low back pain patients. Man Ther, 2010, 15: 482-489. [Medline] [CrossRef]

27) Barker KL, Shamley DR, Jackson D: Changes in the cross-sectional area of multifidus and psoas in patients with unilateral back pain: the relationship to pain and disability. Spine, 2004, 29: E515-E519. [Medline] [CrossRef]

28) Danneels LA, Vanderstraeten GG, Cambier DC, et al.: CT imaging of trunk muscles in chronic low back pain patients and healthy control subjects. Eur Spine J, 2000, 9: 266-272. [Medline] [CrossRef]

29) Hodges PW, Richardson CA: Delayed postural contraction of transversus abdominis in low back pain associated with movement of the lower limb. J Spinal Disord, 1998, 11: 46-56. [Medline] [CrossRef]

30) Cresswell AG, Grundström H, Thorstensson A: Observations on intraabdominal pressure and patterns of abdominal intra-muscular activity in man. Acta Physiol Scand, 1992, 144: 409-418. [Medline] [CrossRef]
31) Hides JA, Stanton WR, McMahon S, et al.: Effect of stabilization training on multifidus muscle cross-sectional area among young elite cricketers with low back pain. J Orthop Sports Phys Ther, 2008, 38: 101-108. [Medline] [CrossRef]

32) Ferreira PH, Ferreira ML, Maher CG, et al.: Changes in recruitment of transversus abdominis correlate with disability in people with chronic low back pain. Br J Sports Med, 2010, 44: 1166-1172. [Medline] [CrossRef]

33) Asghar A, Samane K, Gholam A: The effect of motor control exercise versus general exercise on lumbar local stabilizing muscles thickness: randomized controlled trial of patients with chronic low back pain. JBMR, 2008, 21: 105-112.

34) Hides JA, Stokes MJ, Saide M, et al.: Evidence of lumbar multifidus muscle wasting ipsilateral to symptoms in patients with acute/subacute low back pain. Spine, 1994, 19: 165-172. [Medline] [CrossRef]

35) Danneels LA, Vanderstraeten GG, Cambier DC, et al.: Effects of three different training modalities on the cross sectional area of the lumbar multifidus muscle in patients with chronic low back pain. Br J Sports Med, 2001, 35: 186-191. [Medline] [CrossRef]

36) Lehman GJ, Hoda W, Oliver S: Trunk muscle activity during bridging exercises on and off a Swiss ball. Chiropr Osteopat, 2005, 13: 14. [Medline] [CrossRef]

37) Norwood JT, Anderson GS, Gaetz MB, et al.: Electromyographic activity of the trunk stabilizers during stable and unstable bench press. J Strength Cond Res, 2007, 21: 343-347. [Medline]

38) Narici MV, Roi GS, Landoni L, et al.: Changes in force, cross-sectional area and neural activation during strength training and detraining of the human quadriceps. Eur J Appl Physiol Occup Physiol, 1989, 59: 310-319. [Medline] [CrossRef]

39) Hayden JA, van Tulder MW, Tomlinson G: Systematic review: strategies for using exercise therapy to improve outcomes in chronic low back pain. Ann Intern Med, 2005, 142: 776-785. [Medline] [CrossRef]

40) Rackwitz B, de Bie R, Limm H, et al.: Segmental stabilizing exercises and low back pain. What is the evidence? A systematic review of randomized controlled trials. Clin Rehabil, 2006, 20: 553-567. [Medline] [CrossRef] 